\title{
IMPLEMENTATION AND EVALUATION OF AN IMAGE ANALYSIS SYSTEM FOR DETERMINING VIABILITY OF POLLEN GRAINS IN TEMPERATE RICE
}

\author{
Rodrigo Ortega B. ${ }^{*}$, Macarena Aresti E. ${ }^{1}$, and Iris Pereira R. ${ }^{2}$
}

\begin{abstract}
Geographical and climatic factors limit the production of temperate rice (Oryza sativa L.) in Chile. Large thermal fluctuations of air and water temperatures affect the viability of pollen, causing high levels of spikelet sterility ("blanking"), resulting in reduced yields per hectare. Counting viable pollen grains, at the time of anthesis, may allow determining, ahead, whether there will be yield losses by spikelet sterility; besides, knowing the potential pollen viability serves as a powerful tool for material selection in breeding programs, and for determining which management factors may influence "blanking". If performed manually, counting total and viable pollen grains can be extremely tedious, producing highly variable results. The present work had for objectives to develop and evaluate a system, based on imagery analysis, for counting total and viable pollen in rice anthers. At the time of anthesis, three panicles were collected from plot treatments of two field experiments in which the effects of different management factors (variety, water height, $\mathrm{N}$ rate, and spatial arrangement) on spikelet sterility were evaluated. Two spikelets and four anthers were sampled from each panicle; pollen grains were extracted from anthers and photographed. Manual and digital counts were made on the images to determine total and viable pollen. Digital count was performed with the software SigmaScan Pro, setting some parameters on the imagery before counting. Precision and accuracy of the digital method were estimated. The results indicated that the digital pollen count showed a very good precision and accuracy and could be used to estimate pollen viability, and as a response variable to compare management treatments.
\end{abstract}

Key words: Rice crop, Oryza sativa, pollen counting, image analysis, anthesis, spikelet sterility.

\section{INTRODUCTION}

Rice (Oryza sativa L.) belongs to the Poaceae family; it is considered a semi-aquatic annual grass that can grow either flooded or under dryland conditions (CIAT, 2005). In the world, two main types of rice are grown: the Indica of medium to large size grain, grown in tropical climates; and the Japonica of medium and short grain, usually cultivated in subtropical and temperate climates.

In countries like Chile, Australia, and the State of California in the USA, rice is planted under permanent flood, varying the height of the water table during the different stages of development. Low air or water

${ }^{1}$ Universidad Técnica Federico Santa María, Departamento de Industrias, Av. Santa María 6400, Vitacura, Santiago, Chile. *Corresponding author (rodrigo.ortega@usm.cl).

${ }^{2}$ Universidad de Talca, Instituto de Biología Vegetal y Biotecnología, Av. Lircay s/n, Talca, Chile.

Received: 15 April 2010.

Accepted: 23 September 2010. temperatures (below $20{ }^{\circ} \mathrm{C}$ ), especially during the period of pollen formation, affect the number of viable pollen grains, causing sterility in rice flowers (spikelets), with the consequent losses in production, which can account up to $100 \%$ in cold years (Alvarado, 1999; Ortega, 2007).

Sterility is controlled, in part, by maintaining the growing panicle completely submerged under water, to avoid exposure to cold air temperatures. Varieties producing shorter plants will be less susceptible to sterility because the panicle in formation would be better protected under the water table.

Pollen count is an important tool for research on pollination and on spikelet sterility in particular; usually it is manually done, with a high probability of error, due to sample preparation and/or operator fatigue; for example, when conducting pollen count in rice, high concentrations of pollen grains, spores, and debris can be found in microscope slide, making the manual counting difficult and causing eyestrain. Due to these difficulties, an automated image analysis system that allows fast and 
reliable identification, count, and classification of pollen grains is needed.

Several researchers have worked on developing tools that facilitate pollen count, through better image quality and processing, allowing good estimation of pollen viability with the consequent benefits of saving time and reducing the cost of analysis (Bechar et al., 1997; France et al., 2000; Fox et al., 2001).

The objectives of this study were to implement and evaluate an image analysis system for counting and separating viable pollen grains, to evaluate the performance of digital pollen count versus manual counting, and to evaluate the effect of key agronomic managements on pollen viability, determined by image analysis, and relate it to total spikelet sterility.

\section{MATERIAL AND METHODS}

\section{Sampling, sample preparation and pollen count}

Panicle samples were collected from research plots, subjected to different treatments, located near the city of Parral $\left(36.02^{\circ} \mathrm{S}, 71.88^{\circ} \mathrm{W}\right)$ in the heart of the rice area of Chile; the following experiments were considered for evaluation of pollen viability:

\section{Effect of water height and $\mathbf{N}$ rate on spikelet sterility} on different varieties. Factorial experiment with three replications in a split-block design, of two water heights during panicle initiation $(5$ and $20 \mathrm{~cm})$, four $\mathrm{N}$ rates $(0$, 60, 120, and $240 \mathrm{~kg} \mathrm{~N} \mathrm{ha}^{-1}$ ), and four varieties (Diamante INIA, Oro, Ambar INIA, and Harika-GS). Harika-GS is a new variety, non commercially available at the time, since is under registration process.

Effect of water height, seed rate, $\mathrm{N}$ rate, and spatial arrangement on spikelet sterility. Factorial experiment with three replications in a split-block design, of two water heights (5 and $20 \mathrm{~cm}$ ), four seed rates $(30,60,120$, and $\left.180 \mathrm{~kg} \mathrm{ha}^{-1}\right)$, four $\mathrm{N}$ rates $(0,60,120$, and $240 \mathrm{~kg} \mathrm{~N}$ $\mathrm{ha}^{-1}$ ), and two plant spatial arrangements (broadcast and row), using the variety Diamante INIA.

A total of 288 plots (96 from Experiment 1, and 192 from Experiment 2) were evaluated. In both experiments, $\mathrm{N}$ rates were applied in two equal splits (pre-flood and tillering) with urea $(46 \% \mathrm{~N})$. All treatments had a base of $60 \mathrm{~kg} \mathrm{P}_{2} \mathrm{O}_{5}$ ha $^{-1}$ as triple superphosphate $\left(46 \% \mathrm{P}_{2} \mathrm{O}_{5}\right)$ and $60 \mathrm{~kg} \mathrm{~K}_{2} \mathrm{O}$ ha $^{-1}$ as potassium chloride $\left(60 \% \mathrm{~K}_{2} \mathrm{O}\right)$, incorporated before the flood.

At the time of panicle collection, rice was at anthesis stage, which varied depending upon the evaluated variety. To avoid dehydration, panicles were collected early in the morning, put in paper bags, and transported in insulated coolers to the laboratory. Each sample consisted on three panicles, randomly collected inside each treatment plot; two spikelets were extracted from the medium section of each panicle; four anthers were selected at random from the two spikelets. This was done for each of the 288 plots being evaluated, producing 864 samples to analyze (288 plots $x 3$ panicles per plot). Anthers were introduced in test tubes, immersed in a buffer solution of $10 \mathrm{~mL}$ of sodium acetate $(\mathrm{pH}=5)$, and placed in a water bath at 37 ${ }^{\circ} \mathrm{C}$ throughout the night (modified from Fox et al., 2001); after incubation, anthers were placed in Petri dishes, along with the soaking solution to prepare the final sample for each treatment (Figure 1).

Soaked anthers were taken with a dissecting needle and placed in a solution of one drop of demineralized water and one drop of potassium iodine (KI). Subsequently, the anthers were macerated to release the pollen. Then the solution was suctioned with a dropper and placed on a microscope slide. Each sample was observed with a stereoscope (model EZ4, Leica, Wetzlar, Germany), which is able to capture images by connecting it to a computer through a USB 2.0 cable and proper software. A pollen grain is considered viable if it has starch ("engorged"); therefore in contact with KI it should stain dark.

Images observed under the stereoscope were photographed with a magnification of $32 \mathrm{X}$ and stored in a computer; total and viable pollen were counted with the software SigmaScan Pro 5 (Systat Software, 2008); before automatic counting, images were subjected to the following treatments within the software: 1) addition; each image was added to itself to get a sharper and clearer picture, 2) color intensity, the brightness was increased by $20 \%$, 3) intensity threshold, for the detection of viable pollen, the image was transformed providing intensity values from 0 to 100 ; for counting total pollen, intensity values were from 0 to 135 . For each image two counts were made using the "count objects" function within SigmaScan Pro 5, one for total pollen grain, and the second for viable pollen. Counts were stored in a spreadsheet within the same software for statistical analysis.

In order to make manual pollen counting, the total number of plots for each evaluated field trial was considered as a population. Each population was divided in four groups according to its mean and standard deviation percent viable pollen. Plots were sorted in each of the groups and random samples were drawn from each group. For the first experiment, 16 samples (plots) were drawn, four for each variety, given a total of 48 samples (images) to count; for the second experiment, four plots were selected giving a total of 12 samples to manually count (Table 1). Each selected image was divided up in four quadrants in order to facilitate manual count of viable and total pollen grains. 


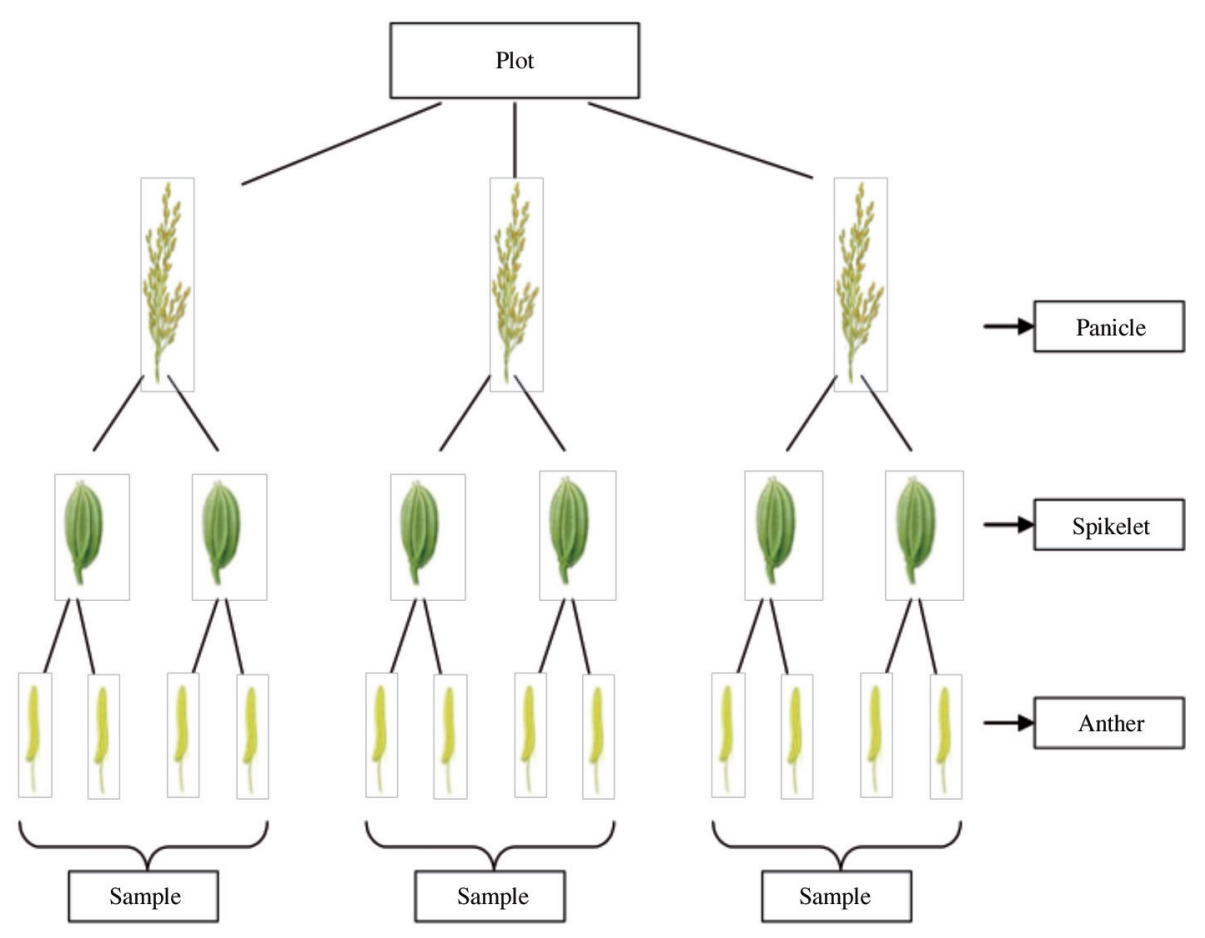

Figure 1. Sampling procedure for pollen count.

Percent viable pollen (PVP) was calculated as the quotient of the number of viable pollen grain and the total pollen grains, as counted either digitally or manually.

Spikelet sterility was determined at harvest on 10 panicles randomly selected on each experimental plot; vain and full rice grains were counted and separated; spikelet sterility was calculated as the quotient between the number of vain grains and the total rice grains.

\section{Statistical analysis}

Performance of digital determination of percent viable pollen. The performance of digital determination of percent viable pollen (PVP) was evaluated in two ways: 1) Precision: estimated by the coefficient of variation (CV) of PVP; and 2) Accuracy: estimated by the absolute deviations in PVP with respect to manual count, which was considered as the "true" value. Average deviation was estimated by regression analysis between manual and digital count, testing the null hypotheses of an intercept equal to zero and a slope equal to one. The analyses were performed in Microsoft Excel, with the whole data set, and also separating it by rice variety.

Assessment of pollen viability and spikelet sterility as affected by rice management. To evaluate the effect of different agronomic managements on percent viable pollen and spikelet sterility in different rice varieties, ANOVA, correlation, and regression analyses were performed with SAS (Statistical Analysis System, SAS Institute, 2000).

Table 1. Simple selection for manual counting.

\begin{tabular}{llcc}
\hline & & \multicolumn{2}{c}{ Number of plots } \\
\cline { 3 - 4 } Group & \multicolumn{1}{c}{ Percentage of viable pollen $($ PVP) } & Exp. 1 & Exp. 2 \\
\hline 1 & PVP < (average - standard deviation) & 4 & 1 \\
2 & (Average - standard deviation) $<$ PVP $<$ Average & 4 & 1 \\
3 & Average $<$ PVP $<$ (average + standard deviation) & 4 & 1 \\
4 & PVP $>$ (average + standard deviation) & 4 & 1 \\
\hline
\end{tabular}




\section{RESULTS AND DISCUSSION}

Performance of digital determination of total pollen, viable pollen, and percent viable pollen

When considering all the data available, which included the four rice varieties and all the evaluated agronomic managements, high correlations between manual and digital count were found for total pollen, viable pollen, and percent viable pollen. These findings closely agree with those of Fox et al. (2001), who also found a good agreement between digital and manual pollen counts, using different software and image settings. Digital count underestimated total and viable pollen, however, both the digital and manual PVP determination gave similar results (Figure 2) as the intercept was equal to zero (95\% confidence interval from -8.9 to 8.0 ) and the slope equal to 1 (95\% confidence interval from 0.899 to 1.175 ). Significant correlations between manual and digital PVP estimation were also found for each variety. In all cases, both methods gave statistically similar results as the intercept and slope for the regression equations were zero and one, respectively (Table 2).

These results indicate that the software and parameters used for the digital count in this study were sensitive and specific enough to distinguish between viable and non viable pollen grains, and discriminate these from the rest of the elements within the image, in all the evaluated varieties.

The average accuracy of the digital count to determine PVP, considering the manual count as the "true" value, was $9 \%$. When stratifying by variety, accuracy varied from $5.8 \%$ for 'Oro' to $16.6 \%$ for 'Ambar INIA', respectively (Table 3); this could be mainly due to morphological and structural differences in the pollen grains of each variety. Adjustments in the image treatment should be done to improve overall accuracy in some varieties.

The global precision of the whole system for digital PVP determination, which included: panicle, spikelet, and anther sampling, sample preparation, and digital analysis was $26.4 \%$ on the average, and varied from 18.4 and $41.6 \%$ for 'Harika-GS' and 'Oro', respectively (Table 3). Most of the variability observed was due to field sampling, since under laboratory conditions this was reduced.

Image analysis with digital count delivered similar results as the one with manual count, providing several benefits and advantages (France et al., 2000); it is many times faster than manual count, saving up 30 min per sample, avoids worker fatigue, and has fewer statistical errors (Bechar et al., 1997; Fox et al., 2001). This modified method can be used to evaluate the effect of climatic and management factors on pollen viability or as a regular tool for rice breeding programs for temperate rice.
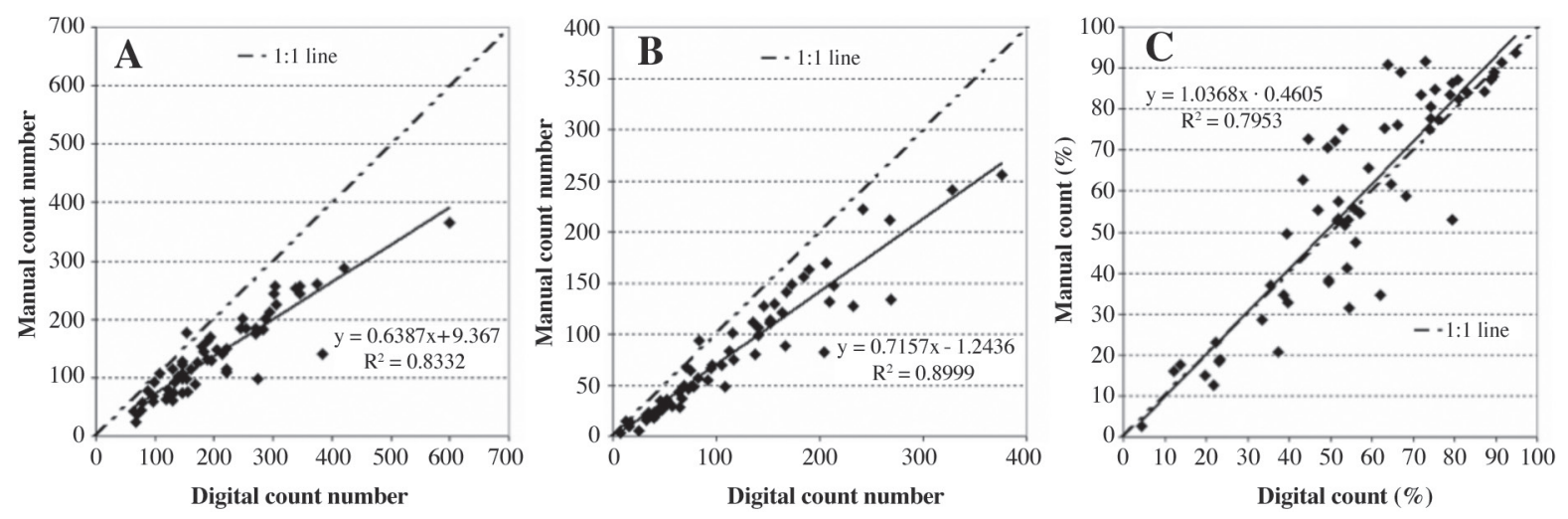

Figure 2. Relationships between digital and manual pollen count for A) total pollen grain, B) viable pollen grains, and C) percent viable pollen.

Table 2. Linear model fit for digital versus manual determination of percent viable pollen in rice.

\begin{tabular}{lcccc}
\hline & & & \multicolumn{2}{c}{ Confidence interval (95\%) } \\
\cline { 4 - 5 } Variety & $\mathbf{n}$ & $\mathbf{r}^{\mathbf{2}}$ & Intercept & Slope \\
\hline Ambar INIA & 12 & 0.58 & -26.2 to 43.2 & 0.399 to 1.610 \\
Diamante INIA & 24 & 0.84 & -11.5 to 14.4 & 0.821 to 1.216 \\
Harika-GS & 12 & 0.81 & -18.9 to 17.5 & 0.618 to 1.270 \\
Oro & 12 & 0.96 & -18.4 to 1.7 & 0.948 to 1.276 \\
\hline Total data set & 60 & 0.80 & -8.9 to 8.0 & 0.899 to 1.175 \\
\hline
\end{tabular}


Table 3. Precision and accuracy of the digital percent viable pollen in rice.

\begin{tabular}{lcc}
\hline Variety & Precision $(\%)$ & Accuracy $(\%)$ \\
\hline Ambar INIA & 21.4 & 16.6 \\
Diamante INIA & 25.4 & 6.5 \\
Harika-GS & 18.4 & 7.0 \\
Oro & 41.6 & 5.8 \\
\hline Average & 26.7 & 9.0 \\
\hline
\end{tabular}

Assessment of pollen viability as affected by variety and rice management

Only significant $(\mathrm{P}<0.05)$ main effects on pollen viability are discussed. On the average, viable pollen represented about $66 \%$ of the total pollen grains (Figure 3); however, differences among varieties were observed; 'Diamante INIA' showed de highest PVP, while 'Harika-GS', had the lowest. On the other hand, 'Harika-GS' had the largest total pollen count and 'Diamante INIA' the lowest; for a proper pollination it is important to have a large value of engorged pollen grains that have the potential for germinating and fecundating the ovules within the spikelets.

When relating pollen viability with spikelet sterility, measured at harvest, a significant $(\mathrm{P}<0.05)$ inverse relationship was found (Figure 4); as expected, spikelet sterility decreased with the increase in pollen viability, however PVP explained only $14 \%$ of the spikelet sterility at harvest; this means that there are other factors other than PVP explaining spikelet sterility; among them, low or high temperatures at anthesis, windy conditions, and nutrient deficiencies which would affect pollen germination and ovule fecundation (Alvarado, 1999; Ortega, 2007). In this regard, Ortega et al. (2009) found

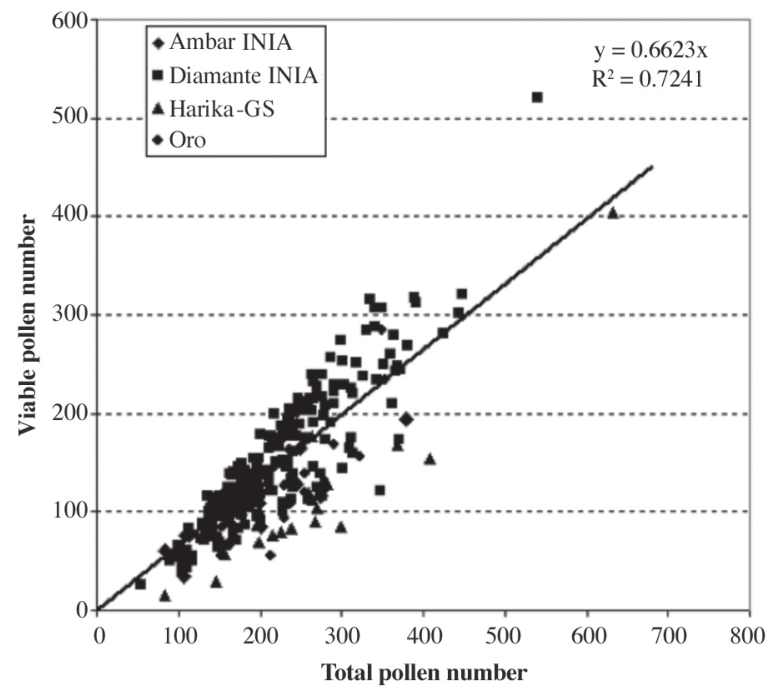

Figure 3. Relationship between total pollen and viable pollen numbers.

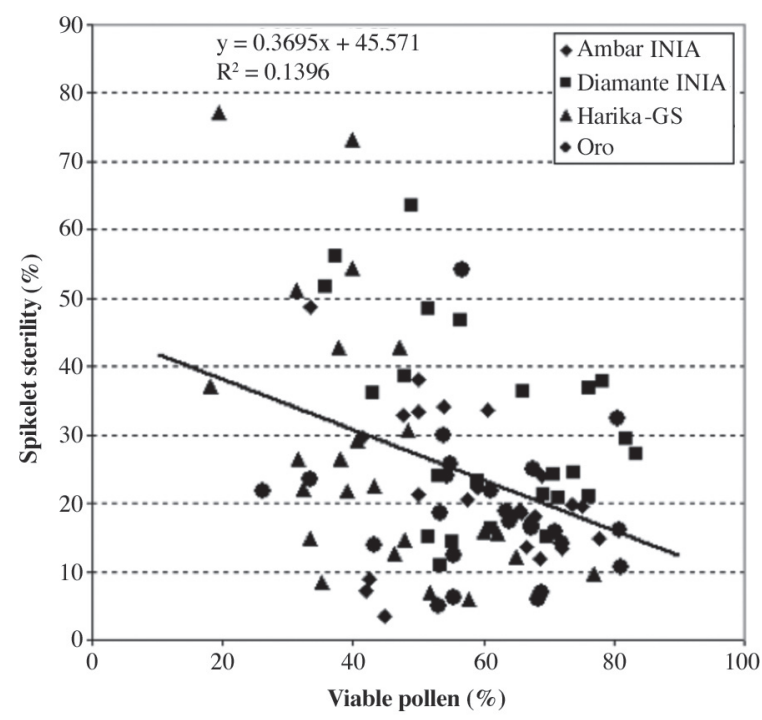

Figure 4. Relationship between percent viable pollen (PVP) and spikelet sterility at harvest.

an inverse relationship between spikelet sterility and the difference in temperature between air and water; which would indicate that high air temperature would also have an effect on blanking. Low water temperature would cause less root development and therefore more competition between reproductive and vegetative parts, inducing more blanking (Farrel et al., 2004).

As expected, pollen viability was affected by water height during pollen formation in both of the evaluated experiments (Figure 5); thus a shallow water table produced less viable pollen, since the panicle in formation

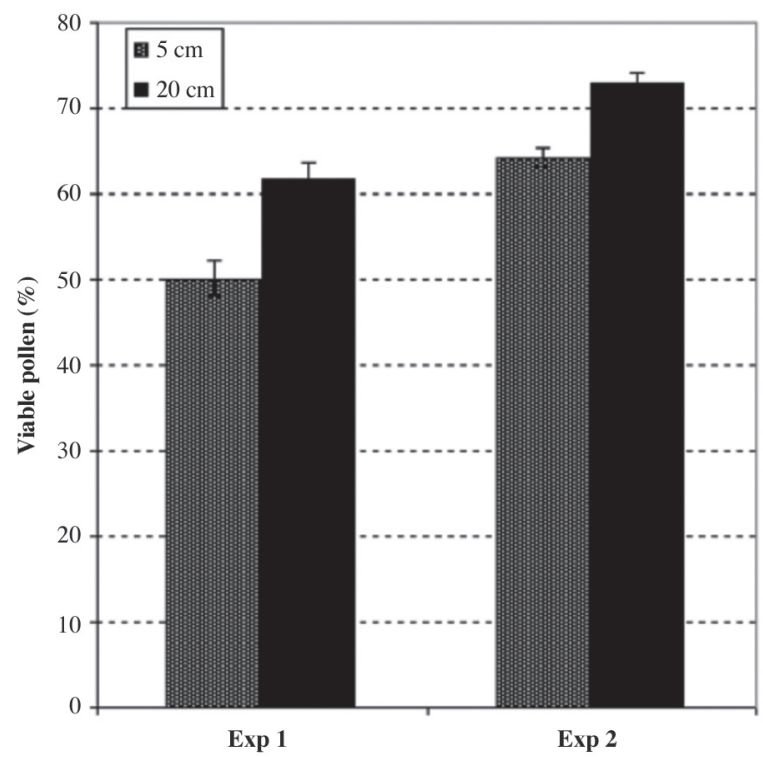

Figure 5. Effect of the water height on pollen viability (average of several varieties and agronomic managements). 
was exposed to the large variation in air temperature from day to night, which is typical at Mediterranean climates, such the Chilean (Shimono et al., 2007).

The effect of $\mathrm{N}$ on PVP was significant only in Experiment 2, with the var. Diamante INIA; a significant decrease in PVP was observed when applying high $\mathrm{N}$ rates, above $120 \mathrm{~kg} \mathrm{~N} \mathrm{ha}^{-1}$ (Figure 6). Decrease in pollen viability by $\mathrm{N}$ effect is usually attributed to competition for carbohydrates between the vegetative and reproductive parts (Roel et al., 2005; Ortega, 2007).

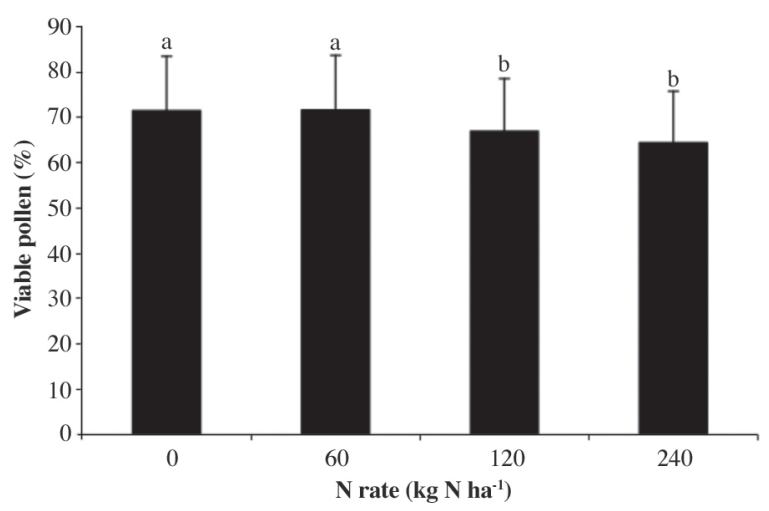

Figure 6. Nitrogen rate effect on pollen viability of var. Diamante INIA (averaged over several agronomic managements).

\section{CONCLUSIONS}

The implemented system to evaluate pollen viability, including sampling, processing, and digital counting worked properly, allowing evaluating the effects of variety and different management factors.

The performance of digital pollen count was satisfactory as the overall accuracy for estimating percent viable pollen was high; across all the evaluated samples, digital estimation of PVP was similar to that obtained by manual count; however, digital count is less time consuming and unbiased compared to the manual one.

Pollen viability, as measured by digital means, was affected by water management and $\mathrm{N}$ rate; however, pollen viability explained only part of the spikelet sterility observed at harvest. Other factors affecting pollen germination and ovule fecundation may be responsible for these differences.

\section{ACKNOWLEDGEMENTS}

This work was supported by the National Fund for Scientific and Technological Development (FONDECYT) under project number 1070179 (Chile). Thanks are given to the Agronomists, Mrs. Carolina Orellana and Mr. David del Solar for their help in this work.

\section{RESUMEN}

Implementación y evaluación de un sistema de análisis de imagen para determinar la viabilidad de granos de polen en arroz templado. La producción de arroz (Oryza sativa L.) en Chile está limitada principalmente por factores geográficos y climáticos. Las grandes variaciones de temperatura del agua y del aire afectan la viabilidad del polen, causando altos niveles de esterilidad floral ("vanazón"), reduciendo los rendimientos del cultivo. Conocer el número de granos de polen viable al momento de antésis permitiría determinar anticipadamente pérdidas de rendimiento por esterilidad floral; además, conocer el potencial de producción de polen viable sirve como una poderosa herramienta de selección en programas de mejoramiento y para determinar el efecto de algunos factores de manejo sobre la "vanazón". El recuento manual de polen total y viable no es práctico produciendo además resultados muy variables. El presente trabajo tuvo como objetivos desarrollar y evaluar un sistema para el recuento de polen viable y total en anteras de arroz, en base a análisis de imágenes. Al momento de antésis se recolectaron tres panículas de cada una de las parcelas de dos experimentos de campo donde se evaluaron los efectos de diferentes factores de manejo (variedad, altura de agua, dosis de $\mathrm{N} \mathrm{y}$ arreglo espacial) sobre la esterilidad floral. Dos espiguillas y cuatro anteras se muestrearon desde cada panícula; los granos de polen fueron extraídos desde las anteras y se fotografiaron. Se realizaron recuentos manuales y digitales sobre las imágenes para determinar el número de polen total y viable. El recuento digital fue realizado con el software SigmaScan Pro, estableciendo algunos parámetros sobre la imagen antes del recuento. El recuento digital de polen alcanzó una buena precisión y exactitud y puede ser usado para estimar la viabilidad del polen y como variable respuesta para comparar tratamientos de manejo.

Palabras clave: cultivo de arroz, Oryza sativa, recuento de polen, análisis de imagen, antésis, esterilidad floral.

\section{LITERATURE CITED}

Alvarado, R. 1999. Influence of air temperature on rice population, length of period from sowing to flowering and spikelet sterility. p. 63-68. In Hill, J.E., and B. Hardy (eds.) Proceedings of the Second Temperate Rice Conference, Sacramento, California, USA. 1317 June. International Rice Research Institute (IRRI), Los Baños, Philippines.

Bechar, A., S. Gan-Mor, Y. Vaknin, I. Shmulevich, B. Ronen, and D. Eisikowitch. 1997. An image-analysis technique for accurate counting of pollen on stigmas. New Phytologist 137:639-643. 
CIAT. 2005. Guía de estudio morfología de la planta del arroz. p. 4-12. Centro Internacional de Agricultura Tropical (CIAT), Cali, Colombia.

Farrel, T.C., K.M. Fox, R.L. Williams, and S. Fukai. 2004. New screening method for cold tolerance during reproductive stage in rice. $4^{\text {th }}$ International Crop Science Congress. Available at http://www.regional. org.au/au/asa/2004/poster/2/7/1/695_farrellt.htm (accessed 23 September 2010).

Fox, K.M., T.C. Farrell, and R.L. Williams. 2001. Rapid image analysis for counting engorged pollen grains of rice. Proceedings of the Australian Agronomy Conference, Australian Society of Agronomy. Available at http://www.regional.org.au/ au/asa/2001/p/5/fox.htm\#TopOfPage (accessed 23 September 2010).

France, I., A.W.G. Duller, G.A.T. Duller, and H.F. Lamb. 2000. A new approach to automated pollen analysis. Quaternary Science Reviews 19:537-546.
Ortega, R. 2007. Analysis of factors affecting spikelet sterility in flooded rice under field conditions in Chile. Archives of Agronomy and Soil Science 53:183-192.

Ortega, R., D. del Solar, and E. Acevedo. 2009. Spatial variability of spikelet sterility in temperate rice in Chile. p. 693-698. In A. Bregt et al. (eds.) Proceeding of the EFITA Conference. Wageningen Academic Publishers, Wageningen, The Netherlands.

Roel, A., R.G. Mutters, J.W. Eckert, and R.E. Plant. 2005. Effect of low water temperature on rice yield in California. Agronomy Journal 97:943-948.

SAS Institute. 2000. SAS user's guide, Version 8.2. SAS Institute, Cary, North Carolina, USA.

Shimono, H., M. Okada, E. Kanda, and I. Arakawua. 2007. Low temperature induced sterility in rice: Evidence for the effects of temperature before panicle initiation. Field Crops Research 101:221-231.

Systat Software. 2008. SigmaScan Pro v. 5.0. Systat Software Inc., Chicago, Illinois, USA. 